\title{
Salivary IgA and IgE levels in healthy subjects: relation to age and gender
}

\begin{abstract}
Abdollah Jafarzadeh(a)
Mostafa Sadeghi(b)

Gholamreza Asadi Karam ${ }^{(c)}$

Reza Vazirinejad (d)
\end{abstract}

(a) Associate Professor of Immunology, Department of Immunology, School of Medicine, Rafsanjan University of Medical Sciences, Rafsanjan, Iran.

(b) Associate Professor of Endodontics, Department of Endodontics, School of Dentistry, Rafsanjan University of Medical Sciences, Rafsanjan, Iran.

(c) Associate Professor of Biochemistry, Department of Biochemistry, School of Medicine, Rafsanjan University of Medical Sciences, Rafsanjan, Iran.

(d) Associate Professor of Epidemiology, Department of Epidemiology, School of Medicine, Rafsanjan University of Medical Sciences, Kermanshah, Iran.

\section{Corresponding author:}

Abdollah Jafarzadeh

Department of Immunology, School of

Medicine, Rafsanjan University of

Medical Sciences

Enghlab Sq. - Rafsanjan - Iran

ZIP: 7719617-996

E-mail: Jafarzadeh14@yahoo.com

Received for publication on Aug 02, 2008 Accepted for publication on Jan 17, 2009

\begin{abstract}
It has been reported that the immune system undergoes age and gender changes. The aim of this study was to investigate the age- and gender-dependent changes of salivary $\operatorname{Ig} \mathrm{A}$ and $\operatorname{IgE}$ levels among healthy subjects. A total of 203 healthy individuals (aged 1-70 years) were enrolled in the study. Two milliliters of saliva were collected from all participants, and salivary $\operatorname{IgA}$ and $\operatorname{IgE}$ levels were measured by the ELISA technique. Mean salivary IgA levels were significantly higher in subjects aged 11-20 years as compared to subjects aged $1-10$ years $(\mathrm{P}<0.01)$. Mean salivary IgA levels increased with age up to the age of 60 years, and then slightly decreased in subjects aged 61-70 years. The frequency of subjects with detectable levels of salivary $\operatorname{IgE}$ and mean salivary $\operatorname{IgE}$ levels gradually increased with age, with maximum levels being observed in the 31-40 years age group and not changing significantly thereafter. The mean levels of salivary $\operatorname{Ig} \mathrm{A}$ and $\operatorname{IgE}$ in adults were significantly higher than those observed in children $(\mathrm{P}<0.00001$ and $\mathrm{P}<0.05$, respectively). No significant differences were observed between men and women regarding both salivary immunoglobulins. These results showed age-dependent changes of the salivary $\operatorname{Ig} \mathrm{A}$ and $\operatorname{IgE}$ levels. Gender had no effect on the salivary levels of $\operatorname{Ig} \mathrm{A}$ and $\operatorname{IgE}$.
\end{abstract}

Descriptors: Saliva; Immunoglobulin A; Immunoglobulin E; Adult; Child.

\section{Introduction}

Secretory $\operatorname{Ig} \mathrm{A}$ is the main immunoglobulin in secretions, including saliva. It is the first line of defense of the host against pathogens which invade mucosal surfaces. ${ }^{1}$ Salivary IgA antibodies could help oral immunity by preventing microbial adherence, neutralizing enzymes, toxins and viruses; or by acting in synergy with other factors such as lysozyme and lactoferrin. ${ }^{1}$ Some studies have also demonstrated a lower incidence of caries as a result of a high salivary IgA concentration. ${ }^{2}$ In addition, low levels of salivary IgA have been presented as a risk factor for upper respiratory infection and have also been associated with an increased risk for periodontal disease and caries. ${ }^{3}$

IgE has an important role in the pathogenesis of some allergic and inflammatory reactions, and an elevated total level of serum IgE has been associated with atopic diseases. ${ }^{4}$ Several studies indicate that nearly every component of the immune system undergoes age-associated alterations. ${ }^{5}$ To our knowledge no papers have been published on the relationship be- 
tween long term variation of salivary $\operatorname{Ig} \mathrm{A}$ and $\operatorname{IgE}$ levels with age and gender. This study was conducted to evaluate age- and gender-related changes of salivary $\operatorname{IgA}$ and $\operatorname{IgE}$ levels in healthy subjects aged $1-70$ years.

\section{Material and Methods Subjects}

A total of 203 healthy subjects (103 men and 100 women, aged 1-70 years) from Rafsanjan (a city located in the Kerman province, Iran) were enrolled in the study. All participants were basically healthy, with no acute or chronic illnesses. Subjects with a history of recurrent infections, asthma, allergy and atopic diseases, or any suspected immunological disorders were excluded from the study, as were those reporting a cigarette smoking habit or use of any drugs. Children were recruited from randomly selected kindergartens, schools and health centers of Rafsanjan city. The adults were recruited among students and staff of the Rafsanjan University of Medical Sciences and health services. Elderly subjects (> 60 years) were selected from the general population of Rafsanjan city and invited to health centers for medical examinations and collection of saliva. Saliva sampling was performed randomly according to the registration number of the participants. An informed consent was obtained from the participants before enrollment in the study. This study was also approved by the Ethical Committee, Rafsanjan University of Medical Sciences. The subjects were divided into 7 groups according to their ages (Table 1).

\section{Collection of the saliva}

All saliva samples were collected at morning between 10 a.m. and 11 a.m. Before collecting the saliva, the subjects had not eaten or drunk for at least $1 \mathrm{~h}$. Approximately 1 hour before collection of the saliva samples, the participants brushed their teeth and washed their oral cavity with sterilized water. Unstimulated whole saliva samples were collected from the mouth on a single occasion, during a period of $5 \mathrm{~min}$. The saliva was collected directly into sterilized tubes, which were then placed on ice. All samples were centrifuged for $15 \mathrm{~min}$ at $10,000 \mathrm{~g}$ and $4{ }^{\circ} \mathrm{C}$ to remove cells and debris. The supernatants were kept at $-70^{\circ} \mathrm{C}$ until used.

\section{Immunoglobulin A quantification in saliva}

Detection of IgA in saliva was performed by sandwich ELISA. In these assays, polystyrene Maxisorb F96 microtitre plates (NUNC, Roskilde, Denmark) were coated overnight at $4^{\circ} \mathrm{C}$ with $0.2 \mu \mathrm{g} /$ well of affinity purified rabbit anti-IgA antibodies with alpha chain-specificity (Beta, Mashhad, Iran) in $0.05 \mathrm{M} \mathrm{NaHCO}_{3}, \mathrm{pH}$ : 9.5. Blocking was performed by use of phosphate buffer containing $0.5 \%$ bovine serum albumin (BSA) at room temperature for $90 \mathrm{~min}$. One hundred microliters of saliva samples (in duplicate) and standard samples (in duplicate) were pipetted into the microtitre wells. The plates were incubated for $90 \mathrm{~min}$ at $37^{\circ} \mathrm{C}$. The wells were washed 5 times with washing solution. Then, $100 \mu \mathrm{l}$ of goat anti-human IgA conjugated with hours radish peroxidase (HRP) were pipetted into each well, and the plates were incubated for $30 \mathrm{~min}$ at $37^{\circ} \mathrm{C}$. The wells were washed 5 times with washing solution and tapped dry. A fresh substrate solution, tetramethylbenzidine $(100 \mu \mathrm{l})$, was added, and the plates were incubated for $15 \mathrm{~min}$ at room temperature. The enzyme reaction was stopped with $100 \mu \mathrm{l}$ of $1 \mathrm{~N} \mathrm{HCl}$. Salivary IgA levels were detected by use of a standard curve. The percent coefficient of variation $(\% \mathrm{CV})$ for this ELISA was $3.8 \%$.

Salivary IgA levels were quantitated by using appropriate dilution of a standard IgA sample with a known concentration of IgA, provided by the manufacturer (Beta, Mashhad, Iran) and expressed as $\mathrm{mg} / \mathrm{dL}$.

\section{Immunoglobulin E quantification in saliva}

Salivary IgE levels were quantitated in duplicate by sandwich ELISA, by using commercial kits (Radim, Pomezia, Italy). Salivary IgE levels were measured by using standard samples with known levels of $\mathrm{IgE}$ provided by the manufacturer and expressed as IU/dL.

\section{Statistical analyses}

The differences in variables were analyzed using the t-test, ANOVA, Mann-Whitney U, Kruskal- 
Table 1 - Variations of the mean salivary $\lg A$ and $\lg E$ levels according to age and gender.

\begin{tabular}{|c|c|c|c|c|c|c|c|}
\hline $\begin{array}{l}\text { Age group } \\
\text { (years) }\end{array}$ & Gender & $\mathrm{n}$ & $\begin{array}{l}\lg A(m g / d L) \\
(\text { mean } \pm S D)\end{array}$ & $\begin{array}{c}\text { Detectable rate } \\
\text { of } \lg E\end{array}$ & $\begin{array}{c}\lg E(I U / d L) \\
(\text { mean } \pm S D)\end{array}$ & $\begin{array}{l}\text { P-value (IgA } \\
\text { differences) }\end{array}$ & $\begin{array}{l}\text { P-value (lgE } \\
\text { differences) }\end{array}$ \\
\hline \multirow{3}{*}{$\begin{array}{c}1-10 \\
\text { (group 1) }\end{array}$} & Male & 14 & $3.99 \pm 2.60$ & $4(28.6 \%)$ & $18.80 \pm 22.15$ & \multirow{3}{*}{-} & \multirow{3}{*}{ - } \\
\hline & Female & 14 & $4.54 \pm 4.88$ & $3(21.4 \%)$ & $23.70 \pm 16.28$ & & \\
\hline & Total & 28 & $4.26 \pm 3.85$ & $7(25 \%)$ & $20.90 \pm 18.45$ & & \\
\hline \multirow{3}{*}{$\begin{array}{c}11-20 \\
\text { (group 2) }\end{array}$} & Male & 16 & $7.78 \pm 5.11$ & $8(50 \%)$ & $70.07 \pm 63.93$ & \multirow{3}{*}{$\begin{array}{l}0.01 \\
\text { (versus group 1) }\end{array}$} & \multirow{3}{*}{$\begin{array}{c}0.3 \\
\text { (versus group 1) }\end{array}$} \\
\hline & Female & 15 & $8.73 \pm 7.95$ & $4(26.7 \%)$ & $151.90 \pm 298.73$ & & \\
\hline & Total & 31 & $8.24 \pm 6.54$ & 12 (38.7\%) & $97.35 \pm 169.00$ & & \\
\hline \multirow{3}{*}{$\begin{array}{c}21-30 \\
\text { (group 3) }\end{array}$} & Male & 16 & $8.96 \pm 6.16$ & 9 (56.25\%) & $79.03 \pm 137.97$ & \multirow{3}{*}{$\begin{array}{c}0.002 \\
\text { (versus group 1) }\end{array}$} & \multirow{3}{*}{$\begin{array}{c}0.2 \\
\text { (versus group 1) }\end{array}$} \\
\hline & Female & 15 & $9.76 \pm 5.57$ & $6(40 \%)$ & $135.33 \pm 217.79$ & & \\
\hline & Total & 31 & $9.35 \pm 5.80$ & 15 (48.4\%) & $101.55 \pm 169.21$ & & \\
\hline \multirow{3}{*}{$\begin{array}{c}31-40 \\
\text { (group 4) }\end{array}$} & Male & 16 & $9.24 \pm 5.61$ & $9(56.25 \%)$ & $61.97 \pm 80.97$ & \multirow{3}{*}{$\begin{array}{c}0.001 \\
\text { (versus group 1) }\end{array}$} & \multirow{3}{*}{$\begin{array}{c}0.05 \\
\text { (versus group 1) }\end{array}$} \\
\hline & Female & 16 & $10.27 \pm 5.47$ & $11(68.75 \%)$ & $187.96 \pm 157.72$ & & \\
\hline & Total & 32 & $9.75 \pm 5.48$ & $20(62.5 \%)$ & $131.27 \pm 141.38$ & & \\
\hline \multirow{3}{*}{$\begin{array}{c}41-50 \\
\text { (group 5) }\end{array}$} & Male & 17 & $10.24 \pm 5.58$ & 9 (52.94\%) & $152.72 \pm 306.57$ & \multirow{3}{*}{$\begin{array}{l}0.0001 \\
\text { (versus group 1) }\end{array}$} & \multirow{3}{*}{$\begin{array}{c}0.2 \\
\text { (versus group 1) }\end{array}$} \\
\hline & Female & 15 & $11.07 \pm 8.10$ & $10(66.66 \%)$ & $83.73 \pm 91.93$ & & \\
\hline & Total & 32 & $10.64 \pm 6.81$ & $19(59.37 \%)$ & $116.41 \pm 217.37$ & & \\
\hline \multirow{3}{*}{$\begin{array}{c}51-60 \\
\text { (group 6) }\end{array}$} & Male & 14 & $10.86 \pm 8.23$ & $7(50 \%)$ & $100.28 \pm 153.00$ & \multirow{3}{*}{$\begin{array}{c}0.0001 \\
\text { (versus group 1) } \\
0.05 \\
\text { (versus group 2) }\end{array}$} & \multirow{3}{*}{$\begin{array}{c}0.1 \\
\text { (versus group 1) }\end{array}$} \\
\hline & Female & 14 & $11.83 \pm 7.78$ & $5(35.7 \%)$ & $177.76 \pm 339.47$ & & \\
\hline & Total & 28 & $11.34 \pm 7.87$ & $12(42.85 \%)$ & $132.56 \pm 237.21$ & & \\
\hline \multirow{3}{*}{$\begin{array}{c}61-70 \\
\text { (group 7) }\end{array}$} & Male & 10 & $7.99 \pm 4.70$ & $4(40 \%)$ & $89.92 \pm 73.63$ & \multirow{3}{*}{$\begin{array}{c}0.006 \\
\text { (versus group 1) }\end{array}$} & \multirow{3}{*}{$\begin{array}{c}0.2 \\
\text { (versus group 1) }\end{array}$} \\
\hline & Female & 11 & $10.48 \pm 7.71$ & $4(36.4 \%)$ & $72.97 \pm 123.10$ & & \\
\hline & Total & 21 & $9.29 \pm 6.42$ & $8(38.1 \%)$ & $81.45 \pm 94.34$ & & \\
\hline \multirow{3}{*}{$\begin{array}{l}\text { All age } \\
\text { groups }\end{array}$} & Male & 103 & $8.50 \pm 5.89$ & 50 (48.54\%) & $86.82 \pm 157.19$ & \multirow{3}{*}{$\begin{array}{c}0.4 \\
\text { (male versus female) }\end{array}$} & \multirow{3}{*}{$\begin{array}{c}0.35 \\
\text { (male versus female) }\end{array}$} \\
\hline & Female & 100 & $9.52 \pm 7.01$ & $43(43 \%)$ & $129.68 \pm 186.15$ & & \\
\hline & Total & 203 & $9.01 \pm 6.47$ & 93 (45.81\%) & $106.63 \pm 171.58$ & & \\
\hline
\end{tabular}

Wallis and Chi-square tests, as appropriate, and $\mathrm{P}$ values of less than 0.05 were considered significant.

\section{Results}

\section{Salivary IgA levels}

The observed age-dependent changes of salivary IgA are presented in Table 1 and Graph 1. Statistical analysis using the ANOVA test showed that there were significant differences among the mean salivary IgA levels of the different age groups $(\mathrm{P}<0.001)$. The mean salivary IgA levels were significantly higher in subjects aged 11-20 years as compared to subjects aged $1-10$ years $(\mathrm{P}<0.01)$. The mean salivary $\operatorname{IgA}$ levels increased with age up to the age of 60 years and then slightly decreased in subjects aged
61-70 years. Similar patterns of salivary IgA alterations were observed in the male and female groups. In each age group, the mean salivary $\operatorname{Ig} \mathrm{A}$ levels tended to be slightly higher in women compared to men, although the differences were not statistically significant. Overall, the mean salivary IgA concentrations in women were higher than in men, but the difference was not significant.

Subjects who were younger than 18 years were considered to be children and those over the age of 18 years were considered as adults. As showed in Table 2, the mean salivary IgA levels in adults were significantly $(\mathrm{p}<0.00001)$ higher than those observed in children. The frequency of subjects with salivary $\operatorname{IgA}$ levels in the $1-2 \mathrm{mg} / \mathrm{dL}$ range was sig- 


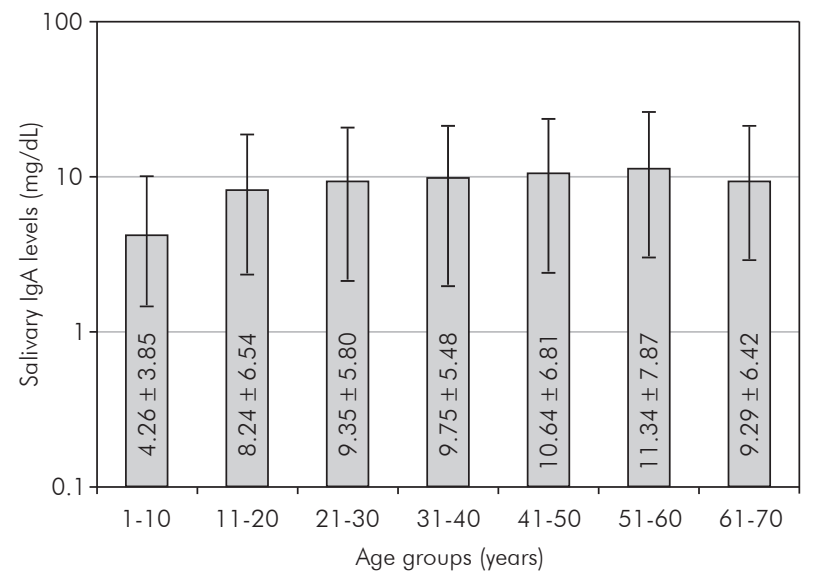

Graph 1 - Mean salivary IgA levels in the different age groups. The mean salivary $\lg A$ levels increased with age. Maximum levels were observed in the 51-60 years age group, and then slightly decreased in the 61-70 years age group.

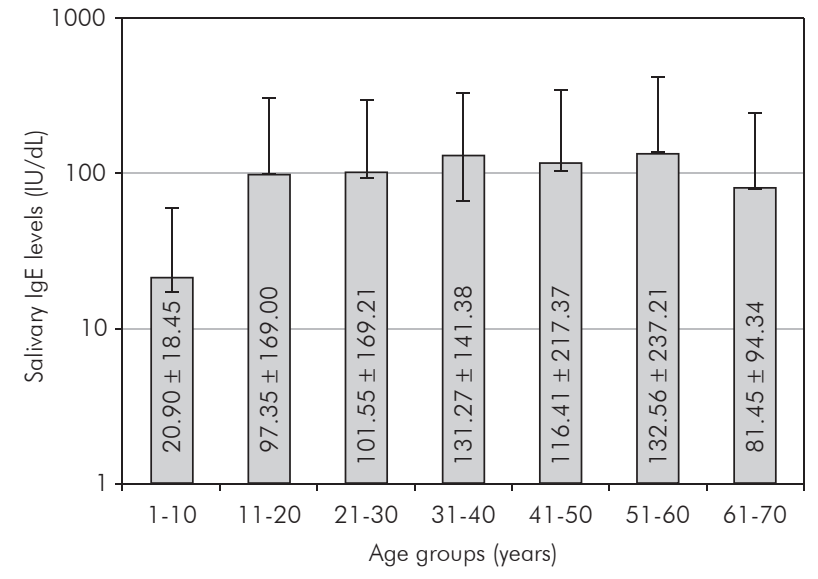

Graph 2 - Mean salivary IgE levels in the different age groups. The mean salivary lgE levels increased with age up to the $31-40$ years age group, and then did not change significantly after the age of 40 years.

Table 2 - Distribution of children and adults according to their salivary lgA and IgE levels.

\begin{tabular}{|c|c|c|c|c|c|}
\hline \multirow{2}{*}{$\begin{array}{c}\text { Salivary } \\
\text { immunoglobulin }\end{array}$} & \multirow{2}{*}{$\begin{array}{l}\text { Ig Concentration } \\
\text { (range) }\end{array}$} & \multicolumn{2}{|c|}{ Children } & \multicolumn{2}{|c|}{ Adults } \\
\hline & & $\%(n)$ & Mean \pm SD & $\%(n)$ & Mean \pm SD \\
\hline \multirow{5}{*}{$\lg A(m g / d L)$} & $1-2$ & $26 \%(13)$ & $1.93 \pm \quad 0.08$ & $0.65 \%(1)$ & $1.94 \pm 0.00$ \\
\hline & $2-5$ & $38 \%(19)$ & $2.92 \pm 0.78$ & $29.41 \%(45)$ & $3.42 \pm \quad 0.74$ \\
\hline & $5-10$ & $16 \%(8)$ & $7.95 \pm 1.31$ & $29.41 \%(45)$ & $7.32 \pm$ \\
\hline & $>10$ & $20 \%(10)$ & $16.54 \pm 3.65$ & $40.52 \%(62)$ & $16.79 \pm$ \\
\hline & Total & $100 \%(50)$ & $6.19 \pm 5.85$ & $100 \%(153)$ & $9.93 \pm$ \\
\hline \multirow{6}{*}{$\lg E(I U / d L)$} & 0 & $68.0 \%(34)$ & $0.0 \pm 0.0$ & $49.7 \% \quad(76)$ & $0.0 \pm 0.0$ \\
\hline & $1-10$ & $12 \%(6)$ & $4.6 \pm 1.8$ & $15 \%(23)$ & $4.39 \pm 2.94$ \\
\hline & $11-50$ & $8 \%(4)$ & $27.5 \pm 8.37$ & $11.8 \% \quad(18)$ & $26.33 \pm 14.06$ \\
\hline & $51-100$ & $6 \%(3)$ & $66.3 \pm 19.58$ & $7.8 \% \quad(12)$ & $76.15 \pm 14.97$ \\
\hline & $>100$ & $6 \%(3)$ & $307.6 \pm 255.3$ & $15.7 \% \quad(24)$ & $298.7 \pm 219.16$ \\
\hline & Total & $100 \%(50)$ & $78.72 \pm 148.9$ & $100 \%(153)$ & $112.43 \pm 176.3$ \\
\hline
\end{tabular}

nificantly higher in children as compared to adults ( $26 \%$ versus $0.65 \% ; \mathrm{P}<0.00001)$. On the other hand, the frequency of subjects with salivary IgA levels $>10 \mathrm{mg} / \mathrm{dL}$ was significantly higher in adults as compared to children $(40.52 \%$ versus $20 \%$; $\mathrm{P}<0.01)$.

\section{Salivary lgE levels}

The frequency of subjects with detectable levels of salivary IgE gradually increased with age up to 40 years (Table 1$)$. The frequency of subjects with detectable levels of salivary IgE was significantly higher in subjects aged 31-40 years as compared to subjects aged $1-10$ years $(\mathrm{P}<0.005)$. The means of salivary IgE levels were calculated only in subjects with detectable levels of salivary IgE. The mean salivary IgE levels also gradually increased with age up to 40 years. The mean salivary $\operatorname{IgE}$ levels were significantly higher in subjects aged $31-40$ years as compared to subjects aged $1-10$ years $(\mathrm{P}<0.05)(\mathrm{Ta}-$ ble $1 \&$ Graph 2). However, the frequency of subjects with detectable levels of salivary $\operatorname{IgE}$ and the 
mean salivary IgE levels did not change significantly after the age of 40 years. No significant differences were observed between men and women regarding both the frequency of subjects with detectable levels of salivary IgE and the mean salivary IgE levels in each age group. Moreover, the mean salivary $\operatorname{IgE}$ concentration in women was higher than that observed in men, but the difference was not significant. As shown in Table 2, the frequency of subjects that had detectable levels of salivary IgE was significantly higher in adults as compared to children $(50.3 \%$ versus $32 \% ; \mathrm{p}<.0 .05)$. Furthermore, the mean salivary $\operatorname{IgE}$ levels in adults was significantly $(\mathrm{p}<0.05)$ higher than that observed in children.

\section{Discussion}

We have demonstrated that the mean salivary IgA levels and the detectable rates of salivary IgE increased with age up to 60 and 40 years, respectively. The salivary levels of both immunoglobulins were higher in adults as compared to children. No significant differences were observed between men and women regarding salivary immunoglobulin levels, which is consistent with findings recently reported in Swedish subjects by Eliasson et al. ${ }^{6}$ (2006). However, the results of a study in healthy elderly persons (age $\geq 76$ years) from Finland has shown that the total salivary IgA levels in women were significantly higher than those observed in men. ${ }^{7}$ Our results demonstrated that the mean levels of salivary $\operatorname{Ig} \mathrm{A}$ and IgE tend to be slightly higher in women as compared to men. The reasons for these differences remain unclear. It has been demonstrated that women have a lower whole saliva secretion rate than men. ${ }^{8}$ Therefore, a differential salivary secretion rate and/ or differential hormonal pattern may account for these observations. In our study, the women/men ratios and the distribution of women and men were similar in all age groups. Accordingly, it seems that this parameter did not interfere with the age-dependent changes of saliva IgA levels.

It has been reported that the salivary secretion rate may inversely influence the IgA concentration in saliva. ${ }^{6}$ Moreover, it has been shown that various factors may influence the secretion rates of saliva, age and gender being the most investigated among them. ${ }^{9}$ The results of some studies have shown that the secretion rate of saliva was lower in women as compared to men. ${ }^{8,9}$ In our study, the similar men/ women ratios in the different age groups may have reduced the effects of the gender-related secretion rate differences on the age-related changes in $\operatorname{Ig} \mathrm{A}$ concentration. Some investigators have also assessed the relationship between age and salivary secretion rate, reporting decreased or unchanged secretion rates of whole saliva with the progression of age. ${ }^{8,10}$ Furthermore, it has also been demonstrated that the reduction of salivary secretion rate with age is the result of disease and medication, and that this phenomenon is not an aging-related event. ${ }^{11}$ Accordingly, it seems that the salivary secretion rate may not be an age-dependent phenomenon in healthy unmedicated adults and elders. Although we did not assess the gender- and age-related changes of salivary secretion rates, employment of the same protocol of saliva sampling and the same inclusion criteria for all age groups may have diminished the influence of the saliva secretion rate on gender- and age-related changes of salivary IgA levels.

Some studies have reported age-related changes of salivary IgA levels. Eliasson et al. ${ }^{6}$ (1996) have reported that salivary IgA levels were higher in elderly subjects ( $\geq 65$ year) as compared to subjects aged 1864 years. Weemaes et al. ${ }^{12}$ (2003) have shown that the salivary $\operatorname{IgA}$ secretion rate increased during infancy and childhood (1-12 years). Childers et al. ${ }^{13}$ (2003) have reported that the levels of $\operatorname{Ig} \mathrm{A}$ increased with age in children (aged 6-12 years, $\mathrm{n}=14$ ) and adults (aged 22-51 years, $\mathrm{n}=20$ ). Challacombe et al. ${ }^{14}$ (1995) showed that the salivary IgA levels increased with age and reached maximum levels in the oldest study group ( $>80$ years). However, in our study the mean salivary IgA levels did not increase after 60 years. Our results regarding the slight drop of salivary IgA concentration after 60 years may be attributed to the increased susceptibility of elderly individuals to oral infectious diseases, especially infection with IgA-degrading bacteria. ${ }^{1}$

We have demonstrated for the first time that the frequency of subjects with detectable levels of salivary $\operatorname{IgE}$ and the mean salivary $\operatorname{IgE}$ levels increased with age up to 40 years and then did not change 
significantly. It has been shown that both environmental and genetic factors exert an influence on the concentration of total serum IgE. ${ }^{15}$ We observed a marked inter-individual variability of salivary $\operatorname{IgE}$ levels in subjects of all age groups. This variability may be attributed to gene polymorphisms involved in $\operatorname{IgE}$ synthesis. Several gene polymorphisms have been related to increased or decreased IgE levels, the strongest association being reported with the IL-13 gene polymorphism. ${ }^{16}$

The immunological basis of the age-dependent changes in salivary IgA and IgE levels could be partly explained by the age-related changes in cytokine production. T-helper 2 (Th2) secretions, especially IL-5, are responsible for IgA production, whereas IL-4 and IL-13 are essential for IgE production by B cells. ${ }^{16,17}$ Moreover, regulatory $\mathrm{T}$ (Treg) cells produce transforming growth factor- $\beta$ (TGF- $\beta$ ), which also induces IgA production and inhibits Th2 cell development. ${ }^{18}$ Regarding the results of the present study,

\section{References}

1. Marcotte H, Lavoie MC. Oral Microbial Ecology and the Role of Salivary Immunoglobulin A. Microbiol Mol Biol Rev. 1998;62(1):71-109.

2. Bratthall D, Serinirach R, Hamberg K, Widerstrom L. Immunoglobulin A reaction to oral streptococci in saliva of subjects with different combinations of caries and levels of mutans streptococci. Oral Microbiol Immunol. 1997;12(4):212-8.

3. Russell MW, Kilian M, Lamm ME. Biological activities of IgA. In: Ogra PL, Mestecky J, Lamm ME, Strober W, Bienenstock J, McGhee JR, eds. Mucosal immunology. San Diego: Academic Press; 1999. p. 225-40.

4. Soresi S, Togias A. Mechanisms of action of anti-immunoglobulin E therapy. Allergy Asthma Proc. 2006;27(2 Suppl 1): S15-23.

5. Pawelec G. Immunity and ageing in man. Exp Gerontol. 2006;41(12):1239-42.

6. Eliasson L, Birkhed D, Osterberg T, Carlén A. Minor salivary gland secretion rates and immunoglobulin $\mathrm{A}$ in adults and the elderly. Eur J Oral Sci. 2006;114(6):494-9.

7. Närhi TO, Tenovuo J, Ainamo A, Vilja P. Antimicrobial factors, sialic acid, and protein concentration in whole saliva of the elderly. Scand J Dent Res. 1994;102(2):120-5.

8. Fenoll-Palomares C, Muñoz Montagud JV, Sanchiz V, Herreros B, Hernández V, Mínguez M et al. Unstimulated salivary flow rate, $\mathrm{pH}$ and buffer capacity of saliva in healthy volunteers. Rev Esp Enferm Dig. 2004;96(11):773-83. an enhancement in the Th2 and Treg cell responses may have accounted for the age-related changes in salivary immunoglobulin levels.

\section{Conclusions}

Based on the results of the present study, it was possible to conclude that age-related alterations of salivary $\operatorname{Ig} \mathrm{A}$ and $\operatorname{IgE}$ levels occur in healthy subjects. The mean salivary IgA levels increased with age up to 60 years and then slightly decreased in subjects aged 61-70 years. The frequency of subjects with detectable levels of salivary $\operatorname{IgE}$ and the mean salivary IgE levels also gradually increased with age up to 40 years. Both parameters of salivary IgE levels did not change significantly thereafter. Moreover, the salivary $\operatorname{Ig} \mathrm{A}$ and $\operatorname{IgE}$ levels were significantly higher in adults as compared to children. No significant differences were observed between men and women regarding salivary immunoglobulin levels.

9. Percival RS, Challacombe SJ, Marsh PD. Flow rates of resting whole and stimulated parotid saliva in relation to age and gender. J Dent Res. 1994;73(8):1416-20.

10. Shern RJ, Fox PC, Li SH. Influence of age on the secretory rates of the human minor salivary glands and whole saliva. Arch Oral Biol. 1993;38(9):755-61.

11. Thorselius I, Emilson CG, Osterberg T. Salivary conditions and drug consumption in older age groups of elderly Swedish individuals. Gerodontics. 1988;4(2):66-70.

12. Weemaes C, Klasen I, Göertz J, Beldhuis-Valkis M, Olafsson $\mathrm{O}$, Haraldsson A. Development of immunoglobulin A in infancy and childhood. Scand J Immunol. 2003;58(6):642-8.

13. Childers NK, Greenleaf C, Li F, Dasanayake AP, Powell WD, Michalek SM. Effect of age on immunoglobulin A subclass distribution in human parotid saliva. Oral Microbiol Immunol. 2003;18(5):298-301.

14. Challacombe SJ, Percival RS, Marsh PD. Age-related changes in immunoglobulin isotypes in whole and parotid saliva and serum in healthy individuals. Oral Microbiol Immunol. 1995;10(4):202-7.

15. Poulsen LK, Hummelshoj L. Triggers of IgE class switching and allergy development. Ann Med. 2007;39(6):440-56.

16. Sadeghnejad A, Karmaus W, Hasan Arshad S, Ewart S. IL-13 gene polymorphism association with cord serum immunoglobulin E. Pediatr Allergy Immunol. 2007;18(4):288-92. 
17. Usui $T$. Transcription factors that regulate helper $\mathrm{T}$ cell differentiation. Nihon Rinsho Meneki Gakkai Kaishi. 2007;30(6):419-27.
18. Taylor A, Verhagen J, Blaser K, Akdis M, Akdis CA. Mechanisms of immune suppression by interleukin-10 and transforming growth factor-beta: the role of $\mathrm{T}$ regulatory cells. Immunology. 2006;117(4):433-42. 